\title{
Characterization of the Events of the Dry Spell in a Basin Northern Tunisia
}

\author{
Majid Mathlouthi and Fethi Lebdi
}

Additional information is available at the end of the chapter

http://dx.doi.org/10.5772/50824

\section{Introduction}

One form of drought is the interruption of the rainy season by a so called dry spell. Dry spell can be defined as a sequence of dry days including days with less than a threshold value of rainfall. The analysis of the historical occurrence of droughts and its probability of recurrence is important. This information is extremely useful for planning and design applications in agriculture and environment and many other sectors. Drought is perceived as a two-dimensional phenomenon (intensity and duration) which is integrated on a spatial basis (regional drought). The two basic dimensions (intensity and duration) require that bivariate frequency analysis is required for linking return periods to both dimensions levels. This approach should be considered as an intermediate step towards a more comprehensive approach, which is related to anticipate damages of specific sectors.

One criticism, however, is that the first-order Markov chain has a relatively short memory that may limit the model's ability to reproduce adequately long dry and/or wet spells, as well as interannual variability [1, 2, 3, 4, 5]. Higher-order Markov chains [6, 7] often improve these inadequacies; however, they require an estimation of more parameters thereby placing stricter demands on the amount of input data. Moreover, the estimation of more parameters results in a higher uncertainty in these parameters and subsequently, the model itself. An alternative to the Markov chain process is to use the wet-dry spell model. This is known as an alternating renewal model, that is, to simulate wet and dry spells separately by fitting their durations to an appropriate probability distribution such as the negative binominal or geometric distribution [2, 6, 8, 9, 10, 11, 12], or empirical distribution [13]. The characteristics of multi-day wet and dry spells is often important for investigating likely scenarios for agricultural water requirements, reservoir operation for analyses of antecedent moisture conditions [8, 14], and runoff generation in a watershed. The main objective of this paper is the event-based analysis of the dry spells based on daily records and the influence of a 
climatic evolution for identifying dry events under Mediterranean climatic conditions. Previous literature on the statistics of dry spells based on daily records is limited. Studies have primarily dealt with the length of dry and wet spells $[10,15,16,17,18,19,20,21]$.

\section{Data}

In Tunisia, regardless of the origin of disturbances, the situations that give rise to copious rainfall remain dependent of important polar meridian flows, especially at altitude. Yet located on the southern margin of the Mediterranean, Tunisia is, wide inter-annual, that very irregularly affected by these flows. In years when the advections of polar air to the south are deep and frequent correspond to rainy periods in the country. In years when the cold air flows are limited in frequency and extension, constitute on the other hand, periods of low rainfall or drought.

So, given the character of atmospheric circulation, rainfall in Tunisia can only be unevenly distributed across seasonal and highly variable inter-annual scale. These same characters of atmospheric circulation are, with the assistance of geographic factors, in the origin of important regional contrasts rainfall.

The case study used as a base for the approach and the methodology of this research is the downstream basin of the Ichkeul Lake, situated in northern Tunisia (Figure 1). This area has a surface of approximately 1500 square kilometres. The wet season extends from September to April, although the beginning or the end of this wet season can move several weeks. Average seasonal precipitation is $600 \mathrm{~mm}$, varies from 450 to $700 \mathrm{~mm}$ following the location and altitude. Mean evaporation (from a free water surface) is around $1490 \mathrm{~mm}$ yearly. The average annual temperature is around $17.5^{\circ} \mathrm{C}$. The rainfalls are recorded in Ghézala-dam rain gauge, from 1968 to 2010 . The mean is $701.3 \mathrm{~mm}$; the coefficient of variation is 0.23 . In this 42-year period the wettest year was recorded in 1995-1996, with $1104.3 \mathrm{~mm}$, and the driest year in 1987-1988, with $408.6 \mathrm{~mm}$. For the monthly rainfall, the mean is $56.8 \mathrm{~mm}$; and the coefficient of variation is 0.67. The wettest month during the period from 1968 to 2010 was February 1996, with $341.1 \mathrm{~mm}$, and the driest month, during the rainy season, was October 2001, with $0.5 \mathrm{~mm}$. On average, for this period, the wettest month was December, with $105.5 \mathrm{~mm}$ of rainfall, and the driest month was May, with $26.8 \mathrm{~mm}$ of rainfall. The wet seasons are separated by dry seasons from almost four months. The rainfall events seem to be grouped over several wet days, separated by dry periods from variable duration. However, rainfall events lasting only one day can be observed. Daily precipitation series, available for a sufficiently long period, of five rain gauges located in this region have been analyzed.

\section{Method}

In the wet-dry spell approach, the time-axis is split up into intervals called wet periods and dry periods (Figure 2). A rainfall event is an interval in which it rains continuously (it is an uninterrupted sequence of wet periods). The definition of event is associated with a rainfall 


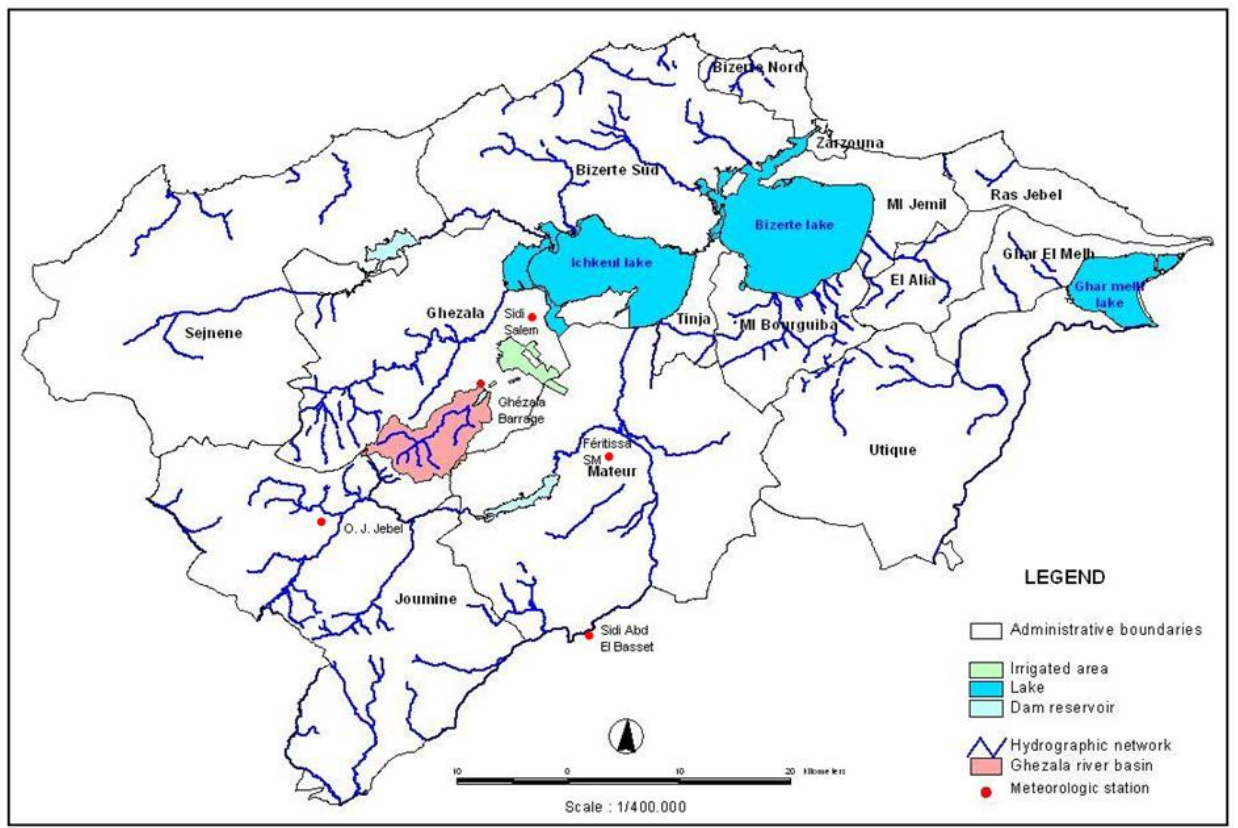

Figure 1. Location of the study area, Tunisia

threshold value which defines wet. The limit $4 \mathrm{~mm}$ day $^{-1}$ has been selected because it corresponds to the average daily evapotranspiration in the area. This amount of water corresponds approximately to the expected daily evaporation rate, thus marking the lowest physical limit for considering rainfall that may produce utilizable surface water resources during the rainy season which lasts from September to April $[8,11]$. In this approach, the process of rainfall occurrences is specified by the probability laws of the length of the wet periods (storm duration), and the length of the dry periods (time between storms or interevent time).

Several distributions have been used for the length of the wet and dry periods; the exponential distribution, the discrete negative binomial distribution "see [11]". For the wet period length, the Weibull distribution has also been used to model short time-increment rainfall occurrences [22]. Other studies used different probability distributions for the length of wet and dry periods $[8,10,23]$.

The varying duration of the events requires that the cumulative rainfall amounts corresponding to each event should be conditioned by the duration of the event. The identification and fitting of conditional probability distributions to rainfall amounts may be problem, especially in the case of short records and for events with extreme (long) durations. 


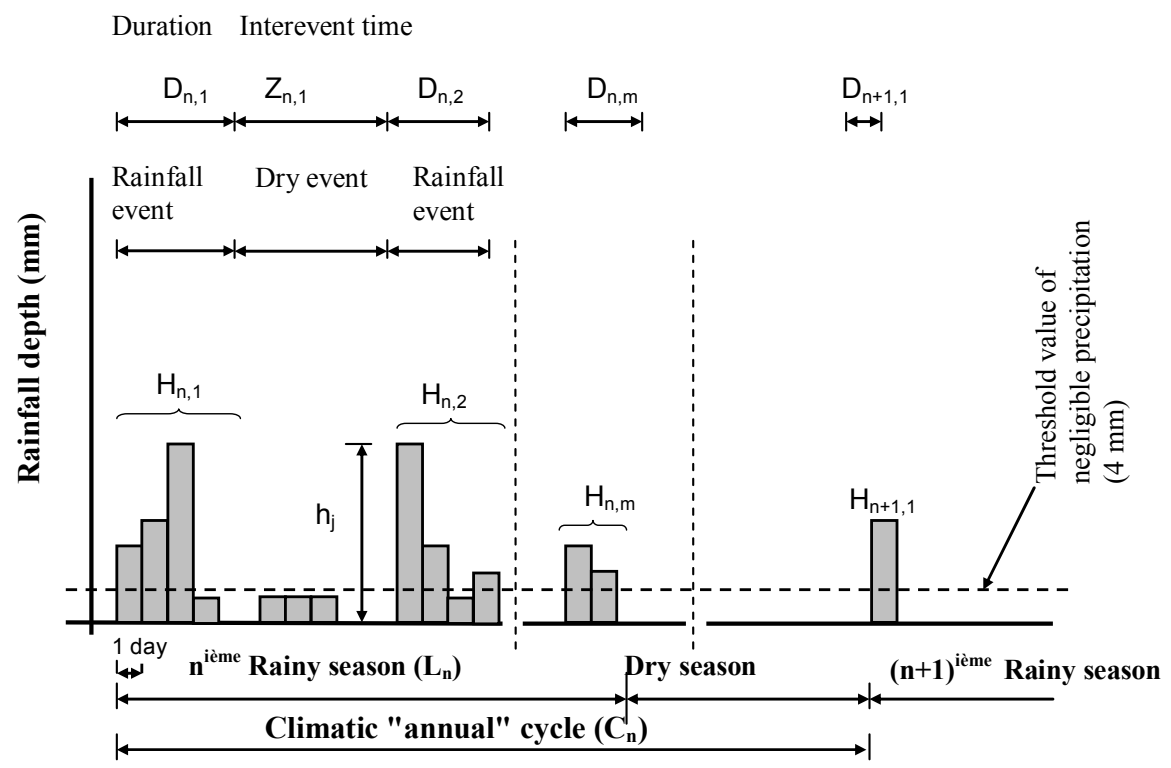

Figure 2. Definitions for the event based analysis

A rainfall event $m$ in a given rainy season $n$ will be characterized by its duration $D_{n, m}$, symbolizing the number of subsequent rainy days, and by the total accumulated rainfall depth of $H_{n, m}$ of $D_{n, m}$ rainy days in $\mathrm{mm}$ [8].

$$
H_{n, m}=\sum_{j=1}^{D_{n, m}} h_{j}, n=1,2, \ldots N \text { and } m=1,2, \ldots M_{n}
$$

Where $N$ is the total number of observed rainy season and $M_{n}$ the number of events/rainy season $n ; h_{j}$ stands for the daily rainfall totals in $\mathrm{mm}$. Note that $h_{j}>0$ and that for at least one $h_{j}>4 \mathrm{~mm}$. In order to define the temporal position of an event within the rainy season, a time parameter is needed. In study of [24], this time parameter is usually the interarrival time. In this investigation, the interarrival time is replaced by the interevent time or dry event $Z_{n, m}$ (Figure 2). Dry event represents the number of days without rainfall between two subsequent rainfall events. The beginning of the first rainfall event in autumn, in September, marks the beginning of the rainy season, while the end of the last rainfall event in spring, in April, marks the term of the rainy season. Thus, a wet season, with variable length, must start with a rainfall event and end with a rainfall event. Thus, the dry season lasts approximately four months. The length of the rainy season is defined as the time span between the start of the first and the end of the last event of the given season; while the "annual" climatic cycle is determined as the time lapsed between the onsets of two subsequent rainy seasons (Figure 2). The climatic cycle define the position of the first rainfall event within the rainy season. However, the length of the year is fixed at 365 days, and it is taken as a constant [8]. 


\section{Results}

\section{Duration of dry events}

If the series of successive precipitations do not form independent events, the waiting time follows a gamma distribution with two parameters instead of an exponential distribution [24]. Consequently, if the time is discretized in days, the distribution of time separating two events is represented by the negative binomial distribution [11,25] which is the equivalent discrete distribution of the gamma distribution:

$$
f(n)=\frac{(r+n-1)}{n !(r-1) !} \cdot p^{r} \cdot q^{n}
$$

where $n=0,1,2, \ldots$ and $r$ and $p$ are estimated by:

$$
r=\frac{m \cdot p}{1-p} ; p=\frac{m}{\sigma_{n}^{2}} ; q=1-p ; m=\bar{n}-1
$$

It is necessary to subtract 1 to $n$ because the negative binomial distribution starts with $n=0$ whereas time separating two events lasts, per definition, at least 1 day $(n=1)$. Consequently $f(n=0)$ is the probability of a dry event lasting 1 day.

As a regression analysis shown, the length of the dry event (time lapsed between rainfall events) or interevent time can be assumed to be independent from all other characteristics of the rainfall event. Thus the distribution of the dry event follows an unconditional probability distribution function. The dry event duration can only assume integer values. As the example Figure 3 reveals, the shortest interruption (one day) is the most frequent one. Almost one fourth of the observed interevent times are only one day long. Nevertheless, the observed range is much longer than that of the rainfall event duration (table 1). Dry periods up to 30 or even days may be recorded (table 2), even though the probability of such extreme length occurring in the middle of the rainy season is small. The very fact that the mean length fluctuates between 7 and 9 days and the high standard deviation are both serious warnings about the unreliability of assuming an evenly distributed precipitation during the rainy season. The univariate negative binomial pdf has been found as best fitted to describe the distribution of the dry event (Figure 3).

\begin{tabular}{|c|c|c|c|c|c|c|}
\hline Rain gauge & $\begin{array}{c}\text { Observation } \\
\text { period }\end{array}$ & $\begin{array}{c}\text { No. of } \\
\text { data } \mathbf{n}\end{array}$ & $\begin{array}{c}\text { Longest observed } \\
\text { in duration days }\end{array}$ & $\begin{array}{c}\text { Arithmetic } \\
\text { mean } \\
\text { (day) }\end{array}$ & $\begin{array}{c}\text { Standard } \\
\text { deviation }\end{array}$ & $\begin{array}{c}\text { Coefficient } \\
\text { of } \\
\text { variation }\end{array}$ \\
\hline Ghézala-dam & $1968 / 2010$ & 895 & 56 & 7.39 & 8.00 & 1.08 \\
\hline O. J. Jebel Antra & $1961 / 2010^{+}$ & 984 & 55 & 7.56 & 8.03 & 1.06 \\
\hline Sidi Salem & $1959 / 2010$ & 1078 & 64 & 7.58 & 8.22 & 1.08 \\
\hline Frétissa & $1982 / 2010$ & 532 & 60 & 8.96 & 9.09 & 1.01 \\
\hline Sidi Abd el Basset & $1968 / 2010^{++}$ & 569 & 81 & 9.18 & 9.49 & 1.03 \\
\hline
\end{tabular}

${ }^{+}$Not observed for 3 years; ${ }^{++}$not observed for 14 years.

Table 1. Parameters of the distribution of the dry event duration in Ichkeul basin 


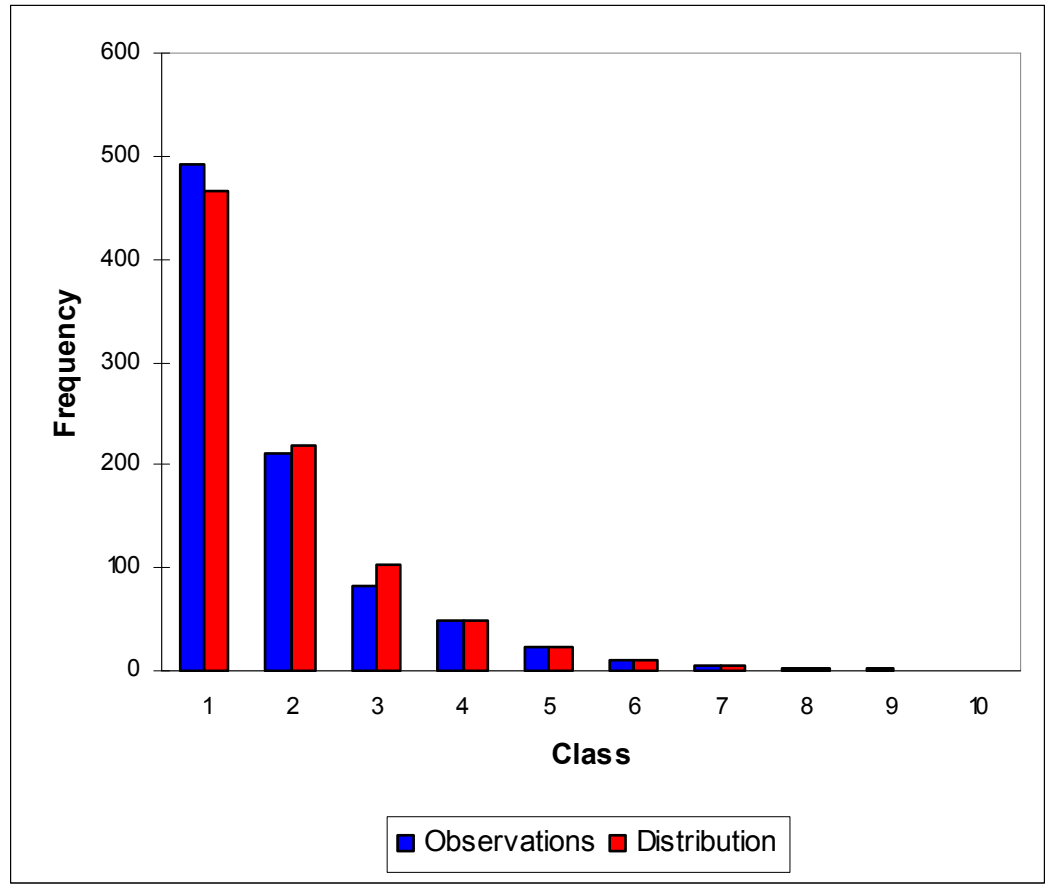

Figure 3. Distribution of dry event duration, O. J. Jebel Antra rain gauge

\begin{tabular}{|c|c|c|c|c|c|c|c|c|}
\hline Rain gauge & $\begin{array}{c}\text { Observation } \\
\text { period }\end{array}$ & $\begin{array}{c}\text { No. of } \\
\text { data }\end{array}$ & $\begin{array}{c}\text { Maximum } \\
\text { no. of } \\
\text { seasonal dry } \\
\text { events } \\
\text { observed }\end{array}$ & $\begin{array}{c}\text { Arithmetic } \\
\text { mean of no. } \\
\text { of dry event } \\
\text { per rainy } \\
\text { season }\end{array}$ & $\begin{array}{c}\text { Standard } \\
\text { deviation of } \\
\text { the no. of } \\
\text { dry event } \\
\text { per rainy } \\
\text { season }\end{array}$ & $\begin{array}{c}\text { Duration of } \\
\text { the } \\
\text { maximum } \\
\text { seasonal dry } \\
\text { event (day) }\end{array}$ & $\begin{array}{c}\text { Arithmetic } \\
\text { mean of the } \\
\text { maximum } \\
\text { seasonal dry } \\
\text { event (day) }\end{array}$ & $\begin{array}{c}\text { Standard } \\
\text { deviation } \\
\text { (day) }\end{array}$ \\
\hline $\begin{array}{c}\text { Ghézala- } \\
\text { dam }\end{array}$ & $1968 / 2010$ & 895 & 30 & 21.31 & 4.39 & 56 & 30.66 & 9.53 \\
\hline $\begin{array}{c}\text { O. J. Jebel } \\
\text { Antra }\end{array}$ & $1961 / 2010^{+}$ & 984 & 30 & 21.39 & 4.30 & 55 & 30.45 & 9.73 \\
\hline Sidi Salem & $1959 / 2010$ & 1078 & 34 & 21.15 & 4.24 & 64 & 30.82 & 10.80 \\
\hline Frétissa & $1982 / 2010$ & 532 & 35 & 20.07 & 4.82 & 60 & 35.37 & 10.83 \\
\hline $\begin{array}{c}\text { Sidi Abd el } \\
\text { Basset }\end{array}$ & $1968 / 2010^{++}$ & 569 & 31 & 20.32 & 5.13 & 81 & 34.53 & 12.66 \\
\hline
\end{tabular}

${ }^{+}$Not observed for 3 years; ${ }^{++}$not observed for 14 years.

Table 2. Comparison of the variability of the number of events/season and that of the maximum seasonal dry event

For planning purposes, the longest dry spells associated with different return periods are of fundamental importance. These values were obtained by modelling this process by GEV (General Extreme Value distributions) distributions which shows the best fit (Figure 4 and 5). Table 3 shows the estimated duration of extreme dry events obtained. From table 3 a few rainy 
seasons characterized by a favourable distribution of rainfall can hide the statistics fact that for a statistical recurrence period of one year, may it produce at least one of more than 20 days (rain gauges of Frétissa and Sidi Abdel Basset). This can be justified by low altitude and unfavourable exposure to rain for these stations (opposite the prevailing wind north-west) and a low annual rainfall in the two rain gauges. For the median the values obtained are critical, the duration of the extreme dry event is almost or more 30 days for all rain gauges; about 4 decades in the Frétissa rain gauge (35 days). For a hundred-year recurrence period, a longest dry spells up to 71.5 days may be registered at Sidi Abdel Basset rain gauge of low average annual rainfall (450 mm).

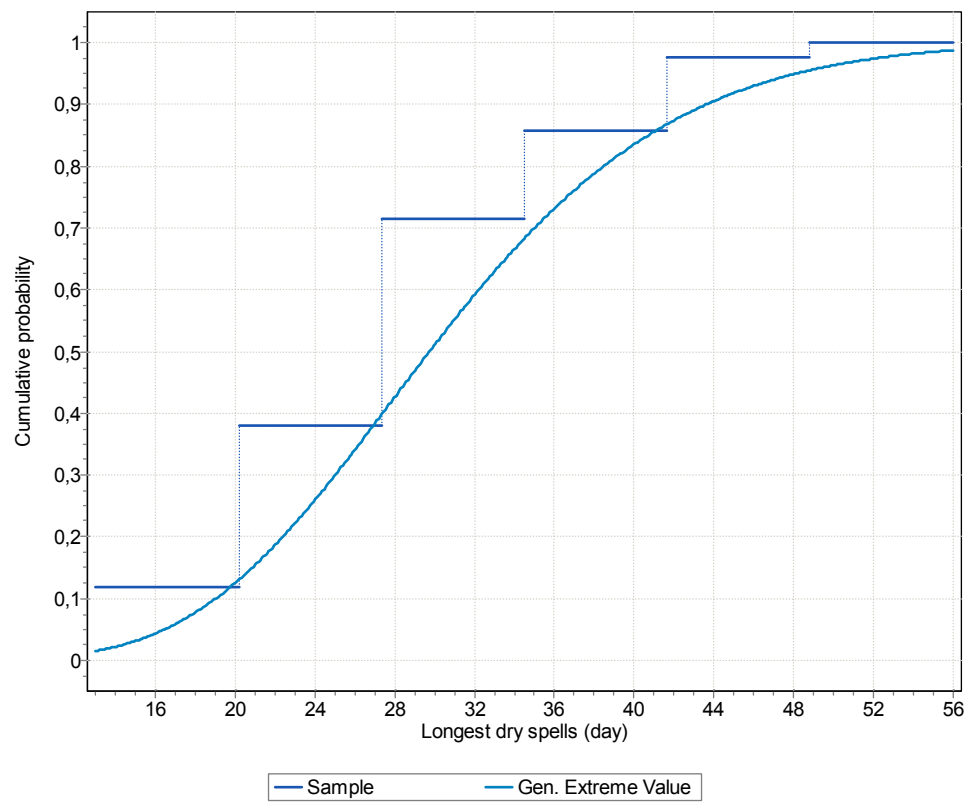

Figure 4. Distribution of the longest dry spell at Ghézala-dam rain gauge

\begin{tabular}{|c|c|c|c|c|c|c|}
\hline $\begin{array}{c}\text { Probability of } \\
\text { exceedance }\end{array}$ & $\begin{array}{c}\text { Return } \\
\text { period }\end{array}$ & Ghézala-dam & $\begin{array}{c}\text { O. J. Jebel } \\
\text { Antra }\end{array}$ & Sidi Salem & Frétissa & $\begin{array}{c}\text { Sidi Abd el } \\
\text { Basset }\end{array}$ \\
\hline 99 & 1.01 & 11.9 & 13.5 & 11.4 & 15.3 & 16.5 \\
\hline 95 & 1.05 & 16.3 & 16.8 & 15.8 & 20.2 & 20.3 \\
\hline 90 & 1.11 & 18.8 & 18.9 & 18.3 & 23.1 & 22.7 \\
\hline 80 & 1.25 & 22.2 & 21.6 & 21.7 & 26.8 & 25.9 \\
\hline 50 & 2 & 29.4 & 28.1 & 29.2 & 35 & 33.5 \\
\hline 20 & 5 & 37.9 & 36.8 & 38.1 & 44.8 & 43.7 \\
\hline 10 & 10 & 42.8 & 42.6 & 43.4 & 50.5 & 50.4 \\
\hline 4 & 25 & 48.2 & 49.8 & 49.5 & 57.1 & 58.9 \\
\hline 2 & 50 & 51.9 & 55.1 & 53.6 & 61.5 & 65.2 \\
\hline 1 & 100 & 55.1 & 60.4 & 57.4 & 65.6 & 71.5 \\
\hline 0.5 & 200 & 58.1 & 65.6 & 60.8 & 69.3 & 77.8 \\
\hline 0.1 & 1000 & 63.8 & 77.7 & 67.9 & 76.8 & 92.2 \\
\hline
\end{tabular}

Table 3. Estimates of extreme dry event durations 


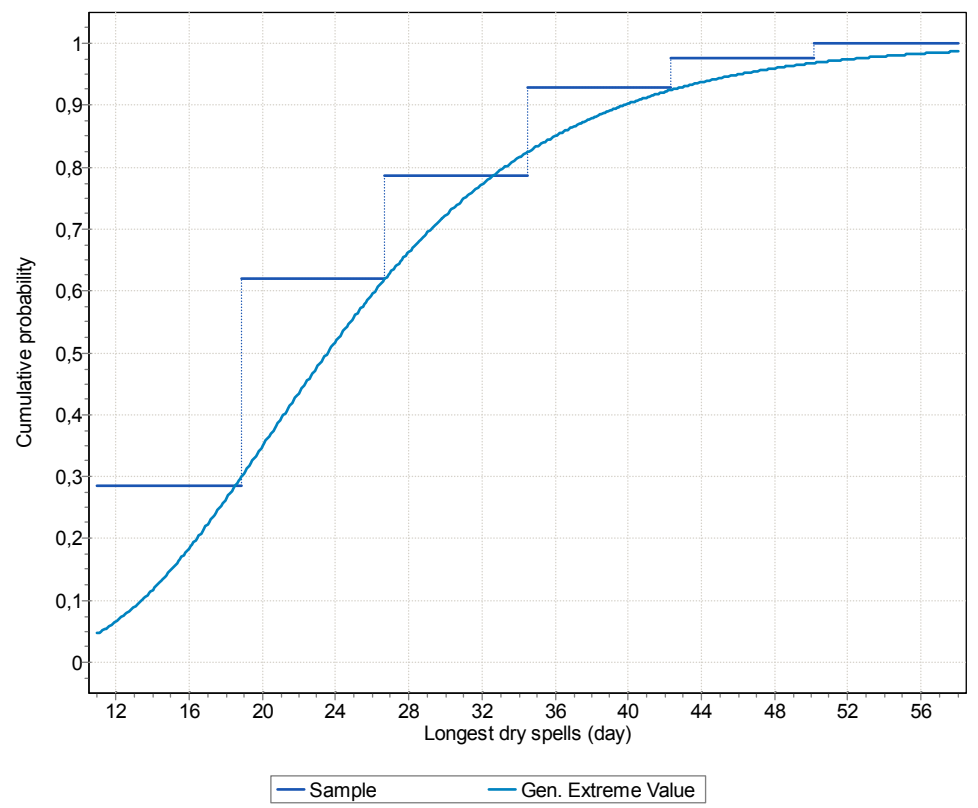

Figure 5. Distribution of the longest dry spell (middle season) at Ghézala-dam rain gauge

To analyze the severity of extreme dry events, the central part of the rainy season for the period from December to March was chosen. Dry events occurring in the core of the rainy season were identified as those ending within the timespan of December - March. Thus any dry event resulting from a rain of start or end of rainy season is not counted. It is important to examine the occurrence of these longest dry spells, during the central part of the rainy season and the whole season, for different return periods. The exceedance probability Pe $(\mathrm{N})$, that an extreme long dry event would occur at least once within a given statistical recurrence period of $\mathrm{T}$ years must be equal to the reciprocal value of the product $\lambda \mathrm{T}$ :

$$
\operatorname{Pe}(N)=\frac{1}{\lambda T}
$$

where $\lambda$ denotes the expected number of dry events/year (season). $\lambda \mathrm{T}$ specifies the expected number of trials needed to observe at least once the extreme duration of $\mathrm{N}$ days associated with the return period of $\mathrm{T}$ years. The length of the extreme dry spell $\mathrm{N}$ can then be obtained from the cumulative negative binomial pdf:

$$
p=1-\operatorname{Pe}(N)=\sum_{n=1}^{N} f(n)
$$

Figure 6 shows the negative binomial distribution fitted to the station Ghézala dam. Table 4 shows the estimated duration of dry events $\mathrm{N}$ obtained by this method. Significant 
differences for a small number of observations between the results obtained using the method of event-based analysis and the extreme seasonal value approach are due to the conceptual difference between these methods. It appears that few rainy seasons characterized by a favorable distribution of rainfall can hide the statistics fact that on 21 or 22 dry events it is likely to produce at least one of more than 24 days.

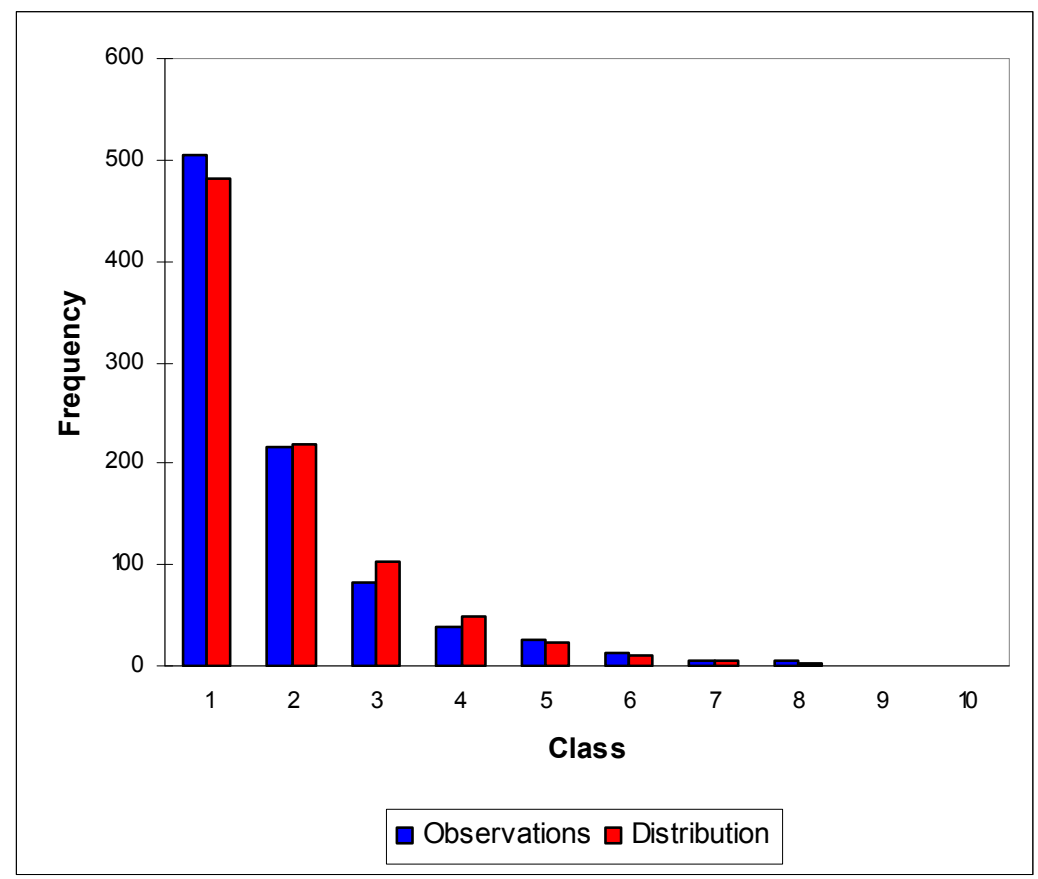

Figure 6. Distribution of the time lapsed between rainfall events (inter-event time), Ghézala Dam rain gauge

\section{Duration of rainfall events}

By focusing on the dry spell event, the duration of the rainfall event $D_{n, m}$ will in fact be identified as inter-event time. This change of roles fits the original Poisson model better. Since rainfall events are shorter, their duration follows the geometrical pdf, as theoretically required. The analysis show that approximately, $50 \%$ of the events indeed last at most one day, the persistence of uninterrupted sequences of rainy days sometimes lasting beyond two weeks (the maximum observed duration is 17 days) (table 5). However the frequency of such long-duration events decreases rapidly with increasing duration. The empirical and fitted geometric pdf of event duration at the Ghézala-dam rain gauge are displayed in Figure 7. 


\begin{tabular}{|c|c|c|c|c|c|}
\hline \multirow[b]{2}{*}{$\begin{array}{l}\text { Probability of } \\
\text { exceedance }\end{array}$} & \multirow{2}{*}{$\begin{array}{l}\text { Statistical } \\
\text { recurrence } \\
\text { period }\end{array}$} & \multicolumn{2}{|c|}{$\begin{array}{l}\text { GEV distribution fitted to the } \\
\text { seasonal extreme values }\end{array}$} & \multicolumn{2}{|c|}{$\begin{array}{l}\text { Model series of non-extreme } \\
\text { values } \\
\text { Negative binomial pdf }\end{array}$} \\
\hline & & $\begin{array}{l}\text { Maximum number } \\
\text { of dry days in the } \\
\text { core of the rainy } \\
\text { season }\end{array}$ & $\begin{array}{c}\text { Extreme } \\
\text { number of dry } \\
\text { days in the } \\
\text { rainy season }\end{array}$ & $\begin{array}{c}\text { Duration of } \\
\text { the seasonal } \\
\text { extreme event }\end{array}$ & $\begin{array}{l}\text { Expected value of } \\
\text { the sample size to } \\
\text { be considered }\end{array}$ \\
\hline 99 & 1.01 & 6 & 11 & 23 & 21.52 \\
\hline 95 & 1.05 & 10 & 16 & 24 & 22.37 \\
\hline 90 & 1.11 & 12 & 18 & 25 & 23.65 \\
\hline 80 & 1.25 & 16 & 22 & 26 & 26.63 \\
\hline 50 & 2 & 24 & 29 & 29 & 42.62 \\
\hline 20 & 5 & 34 & 38 & 36 & 106.55 \\
\hline 10 & 10 & 40 & 43 & 42 & 213.1 \\
\hline 4 & 25 & 48 & 48 & 49 & 532.75 \\
\hline 2 & 50 & 53 & 52 & 55 & 1065.5 \\
\hline 1 & 100 & 58 & 56 & 56 & 2131 \\
\hline 0.5 & 200 & 63 & 59 & 58 & 4262 \\
\hline 0.1 & 1000 & 74 & 65 & 65 & 21310 \\
\hline
\end{tabular}

Table 4. Estimates of extreme dry event durations at Ghézala-dam rain gauge

\begin{tabular}{|c|c|c|c|c|c|c|}
\hline Rain gauge & $\begin{array}{c}\text { Observation } \\
\text { period }\end{array}$ & $\begin{array}{c}\text { No. of } \\
\text { data n }\end{array}$ & $\begin{array}{c}\text { Longest } \\
\text { observed in } \\
\text { duration days }\end{array}$ & $\begin{array}{c}\text { Arithmetic } \\
\text { mean (day) }\end{array}$ & $\begin{array}{c}\text { Standard } \\
\text { deviation }\end{array}$ & $\begin{array}{c}\text { Coefficient } \\
\text { of variation }\end{array}$ \\
\hline Ghézala-dam & $1968 / 2010$ & 937 & 13 & 2.89 & 1.98 & 0.68 \\
\hline O. J. Jebel Antra & $1961 / 2010^{+}$ & 1029 & 16 & 2.62 & 1.85 & 0.70 \\
\hline Sidi Salem & $1959 / 2010$ & 1129 & 17 & 2.53 & 1.83 & 0.72 \\
\hline Frétissa & $1982 / 2010$ & 569 & 11 & 2.32 & 1.63 & 0.70 \\
\hline $\begin{array}{c}\text { Sidi Abd el } \\
\text { Basset }\end{array}$ & $1968 / 2010^{++}$ & 597 & 10 & 1.89 & 1.21 & 0.64 \\
\hline
\end{tabular}

${ }^{+}$not observed for 3 years; ${ }^{++}$not observed for 14 years.

Table 5. Parameters of the distribution of the rainfall event duration in Ichkeul basin

\section{Number of events per rainy season}

By taking account of the assumption of the sequential independence of the rainfall events, as formulated above, the Poisson density function should adequately describe the distribution of the number of events per season:

$$
f(N, \lambda)=\frac{e^{-\lambda} \lambda^{N}}{N !}, N=0,1,2, \ldots
$$

Where $N$ described the number of events during a rainy season. The parameter is the average number of events per rainy season. 


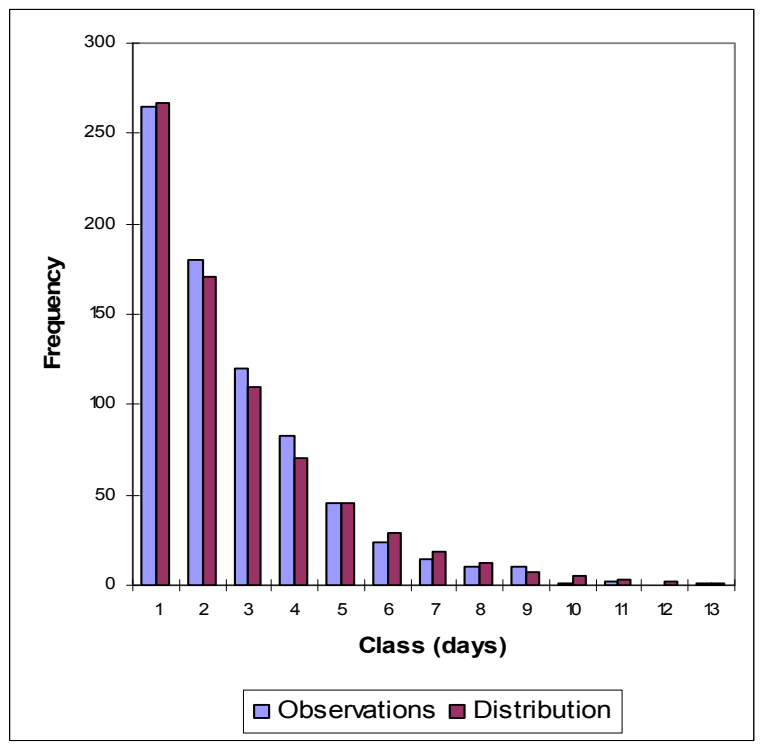

Figure 7. Distribution of rainfall event duration, Ghézala-dam rain gauge

Figure 8 shows the fitted Poisson probability density function. Table 6 summarizes the parameters of the pdfs for all rain gauges. The arithmetic mean is 22.31 and the standard deviation 4.39 for Ghézala-dam rain gauge. The goodness-of-fit has been assessed by the Kolmogorov-Smirnov test at the $95 \%$ significance level. The arithmetic mean appears to provide a stable estimate of the parameter $\lambda$ of the Poisson pdf, since this statistic is also the maximum likelihood estimator; it is used to estimate $\lambda$, in preference to the sample variance, which shows more substantial fluctuations [23].

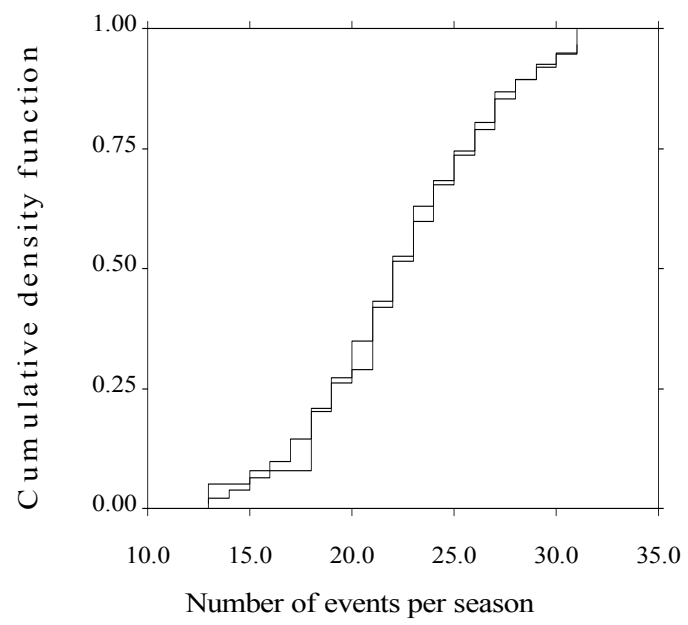

Figure 8. Distribution of the number of rainfall events per season, Ghézala-dam rain gauge 


\begin{tabular}{|c|c|c|c|c|c|c|}
\hline Rain gauge & $\begin{array}{c}\text { Observation } \\
\text { period }\end{array}$ & $\begin{array}{c}\text { No. of } \\
\text { data } \mathbf{n}\end{array}$ & $\begin{array}{c}\text { Maximum } \\
\text { no. of } \\
\text { seasonal } \\
\text { rainfall } \\
\text { events } \\
\text { observed }\end{array}$ & $\begin{array}{c}\text { Arithmetic } \\
\text { mean of } \\
\text { no. of } \\
\text { rainfall } \\
\text { event per } \\
\text { rainy } \\
\text { season }\end{array}$ & $\begin{array}{c}\text { Standard } \\
\text { deviation } \\
\text { of the no. } \\
\text { of } \\
\text { rainfall } \\
\text { event per } \\
\text { rainy } \\
\text { season }\end{array}$ & $\begin{array}{c}\text { Variance } \\
\text { of the } \\
\text { no. of } \\
\text { rainfall } \\
\text { event per } \\
\text { rainy } \\
\text { season }\end{array}$ \\
\hline Ghézala-dam & $1968 / 2010$ & 42 & 31 & 22.31 & 4.39 & 19.34 \\
\hline $\begin{array}{c}\text { O. J. Jebel } \\
\text { Antra }\end{array}$ & $1961 / 2010^{+}$ & 46 & 31 & 22.39 & 4.30 & 18.51 \\
\hline Sidi Salem & $1959 / 2010$ & 51 & 35 & 22.15 & 4.24 & 18.01 \\
\hline Frétissa & $1982 / 2010$ & 27 & 36 & 21.07 & 4.82 & 23.30 \\
\hline $\begin{array}{c}\text { Sidi Abd el } \\
\text { Basset }\end{array}$ & $1968 / 2010^{++}$ & 28 & 32 & 21.32 & 5.13 & 26.37 \\
\hline
\end{tabular}

${ }^{+}$not observed for 3 years; ${ }^{++}$not observed for 14 years.

Table 6. Parameters of the distribution of the number of rainfall event per season in Ichkeul basin

\section{Length of the climatic cycle}

The phenomenon of a rainy season followed by a dry season constitutes an annual cycle. As shown in table 7, the expected value of the cycle confirms the annual characteristic of this phenomenon, and the low coefficient of variation indicates the stability of this expected value. Nevertheless, a negative skewness can be consistently observed. The log Pearson type III pdf provides a good fit to distribution of the length of the climatic cycle. Figure 9 presents an example of empirical versus fitted theoretical pdf.

It is found that a climatic cycle with an above average length is generally followed by a shorter one, thus preventing any long lasting shift of the rainy season.

\begin{tabular}{|c|c|c|c|c|c|}
\hline Rain gauge & $\begin{array}{c}\text { No. of data } \\
\text { points }\end{array}$ & $\begin{array}{c}\text { Arithmetic } \\
\text { mean (day) }\end{array}$ & $\begin{array}{c}\text { Standard } \\
\text { deviation }\end{array}$ & $\begin{array}{c}\text { Coefficient } \\
\text { of variation }\end{array}$ & $\begin{array}{c}\text { Coefficient } \\
\text { of } \\
\text { skewness }\end{array}$ \\
\hline Ghézala-dam & 42 & 364.6 & 15.25 & 0.042 & 0.355 \\
\hline Oued J. Jebel Antra & 45 & 364.1 & 18.34 & 0.050 & 0.196 \\
\hline Sidi Salem & 50 & 365.6 & 22.87 & 0.063 & -0.007 \\
\hline Frétissa SM & 26 & 368.2 & 23.49 & 0.064 & -0.375 \\
\hline Sidi Abd el Basset & 27 & 364.7 & 17.94 & 0.049 & $-0,306$ \\
\hline
\end{tabular}

Table 7. Statistical parameters for the length of the climatic cycle in Ichkeul basin 


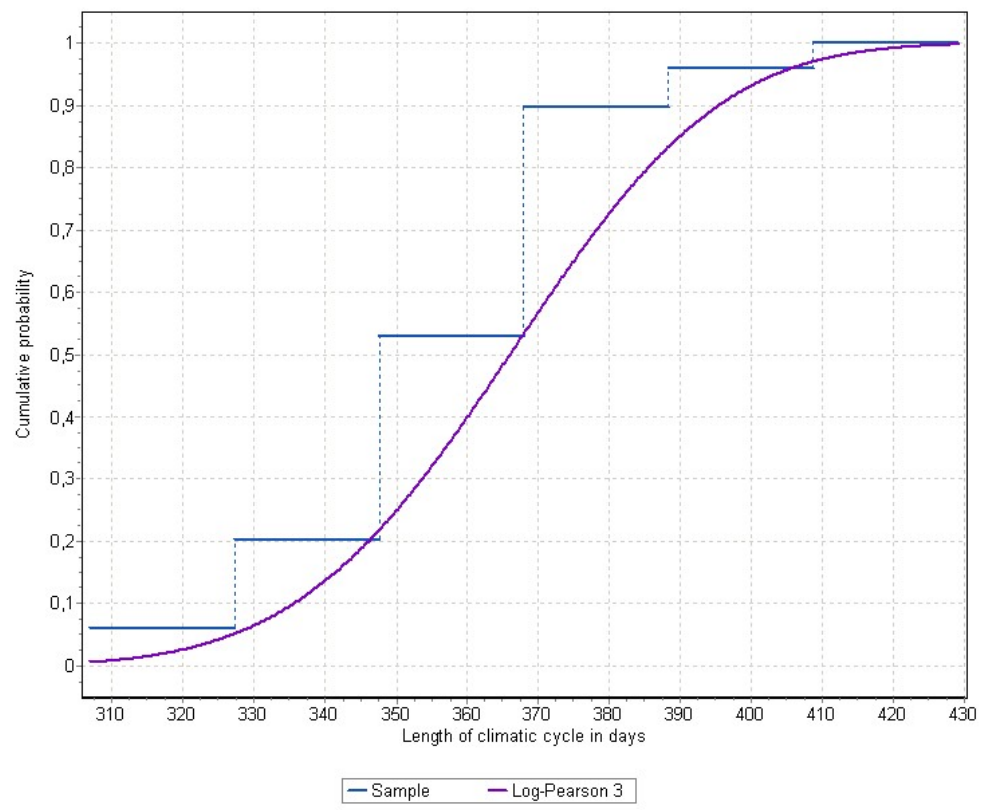

Figure 9. Distribution of the length of the climatic cycle, Sidi Salem rain gauge

\section{Critical of the influence of a climatic evolution}

In order to carry out a criticism of the influence of a climatic evolution three cases are considered for the Ghézala-dam rain gauge: i) the complete daily precipitation series, ii) series divided into two sub-series, iii) series divided into three sub-series. Table 8 shows the calculated statistics for Ghézala-dam rain gauge.

From the data available at the Ghézala-dam rain gauge, it is possible to bring to the force the non-stationarity of the rainfall time-series for the period from 1968 to 2010. It is possible to isolate the periods of rainfall anomaly (strongly rainy periods or drought). One try to evaluate the behaviour of some statistical methods largely employed in research of climatic variability.

Simulated variability is that of a brutal change of the average. The procedures concerned are the Pettitt and Buishand test [26] (see Figure 10 and 11). Since the p-value calculated ( 0.374 for the Pettitt test and 0.652 for Buishand test) are greater than the significance level alpha $=0.05$, we can not reject the null hypothesis $\mathrm{H} 0$ stating that the data are homogeneous. The risk of rejecting the null hypothesis H0 even tough is true is $37.37 \%$ for Pettitt test and $65.19 \%$ for Buishand test. The results show that the null assumption (absence of rupture) is accepted at 99 $\%$ significance level around the p-value. The threshold value $4 \mathrm{~mm} \mathrm{day}^{-1}$ was selected. Table 9 summarizes the statistical characteristics of dry events for Ghézala-dam rain gauge in this hypothesis. It indicates that for the second period (89-2010), the maximum number of observed 
seasonal dry events is identical to the complete time series, whereas that of the first period (6889), it is slightly inferior. The arithmetic mean of maximum seasonal dry events differs respectively during the two periods. The larger the standard deviation is high; east the dispersion of the observations of a variable. Consequently compared with the complete time series, the time series of the second period (89-2010) is dispersed.

\begin{tabular}{|c|c|c|c|c|c|c|}
\hline $\begin{array}{c}\text { Period of } \\
\text { observation }\end{array}$ & $\begin{array}{c}\text { No. of } \\
\text { data }\end{array}$ & $\begin{array}{c}\text { Minimum } \\
\text { annual } \\
\text { precipitation } \\
\text { (mm) }\end{array}$ & $\begin{array}{c}\text { Maximum } \\
\text { annual } \\
\text { precipitation } \\
\text { (mm) }\end{array}$ & $\begin{array}{c}\text { Arithmetic } \\
\text { mean of } \\
\text { annual } \\
\text { precipitation } \\
\text { (mm) }\end{array}$ & $\begin{array}{c}\text { Standard } \\
\text { deviation of } \\
\text { annual } \\
\text { precipitation }\end{array}$ & $\begin{array}{c}\text { Coefficient of } \\
\text { variation of } \\
\text { annual } \\
\text { precipitation }\end{array}$ \\
\hline $1968 / 2010^{+}$ & 42 & 408.6 & 1104.3 & 701.39 & 168.03 & 0.23 \\
\hline $1968 / 1989^{*}$ & 21 & 408.6 & 960.7 & 671.90 & 128.82 & 0.19 \\
\hline $1989 / 2010^{*}$ & 21 & 420.3 & 1104.3 & 730.88 & 198.65 & 0.27 \\
\hline $1968 / 1982 \$$ & 14 & 514.4 & 903.6 & 671.31 & 107.68 & 0.16 \\
\hline $1982 / 1996 \$$ & 14 & 408.6 & 1104.3 & 720.17 & 218.49 & 0.30 \\
\hline $1996 / 2010^{\$}$ & 14 & 461.9 & 940.8 & 712.70 & 167.99 & 0.23 \\
\hline
\end{tabular}

${ }^{+}$complete time series, ${ }^{*}$ two sub-series, $\$$ three sub-series.

Table 8. Statistics of the annual precipitation at the Ghézala-dam rain gauge

The maximum dry event (56 days) was occurred during the second period. Similarly, the maximum arithmetic mean value of the longest duration is during this period. However, the coefficient of variation, which represents the dispersion of the observations, is practically identical to the complete time series. The maximum number of observed seasonal dry events is recorded during the second period (82-96) and the third period (96-2010). For the later period, the arithmetic mean is approximately equal to that of the complete time series. A different standard deviation shows dispersion more distinguished during this period (96-2010). The maximum dry event occurred during the period (82-96). The average duration of the longest dry event is more remarkable during the last two periods (82-96) and (96-2010). A standard deviation, during the period (82-96), is much more significant (12.82) explaining a more significant dispersion of this series (C.V. $=0.40$ while C.V. $=0.31$ for the complete time series).

\begin{tabular}{|c|c|c|c|c|c|c|c|}
\hline $\begin{array}{c}\text { Period of } \\
\text { observation }\end{array}$ & $\begin{array}{c}\text { No. } \\
\text { of } \\
\text { data }\end{array}$ & $\begin{array}{c}\text { Maximum } \\
\text { no. of } \\
\text { seasonal dry } \\
\text { events } \\
\text { observed }\end{array}$ & $\begin{array}{c}\text { Arithmetic } \\
\text { mean of no. } \\
\text { of dry event } \\
\text { per rainy } \\
\text { season }\end{array}$ & $\begin{array}{c}\text { Standard } \\
\text { deviation of } \\
\text { the no. of } \\
\text { dry event } \\
\text { per rainy } \\
\text { season }\end{array}$ & $\begin{array}{c}\text { Duration of } \\
\text { the } \\
\text { maximum } \\
\text { seasonal dry } \\
\text { event (day) }\end{array}$ & $\begin{array}{c}\text { Arithmetic } \\
\text { mean of the } \\
\text { maximum } \\
\text { seasonal dry } \\
\text { event (day) }\end{array}$ & $\begin{array}{c}\text { Standard } \\
\text { deviation } \\
\text { (day) }\end{array}$ \\
\hline $1968 / 2010^{+}$ & 42 & 30 & 21.31 & 4.39 & 56 & 30.66 & 9.53 \\
\hline $1968 / 1989^{*}$ & 21 & 28 & 22.04 & 4.08 & 46 & 28.04 & 8.34 \\
\hline $1989 / 2010^{*}$ & 21 & 30 & 20.57 & 4.67 & 56 & 33.28 & 10.11 \\
\hline $1968 / 1982^{\$}$ & 14 & 27 & 23.14 & 2.71 & 40 & 28.28 & 5.83 \\
\hline $1982 / 1996$ & 14 & 30 & 19.78 & 5.60 & 56 & 31.85 & 12.82 \\
\hline $1996 / 2010^{\$}$ & 14 & 30 & 21.00 & 4.00 & 47 & 31.85 & 8.87 \\
\hline
\end{tabular}

${ }^{+}$complete series, ${ }^{*}$ two sub-series, $\$$ three sub-series.

Table 9. Comparison of the variability of the number of events/season and that of the maximum seasonal event, Ghézala-dam rain gauge. 


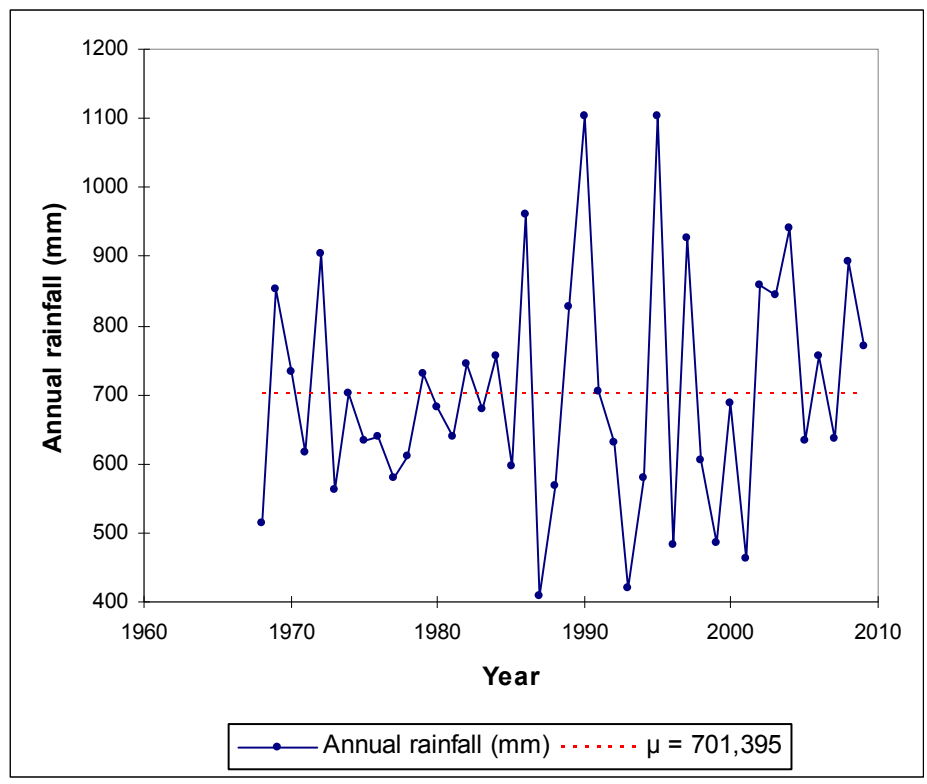

Figure 10. Test of Pettitt for the annual precipitation, Ghézala-dam rain gauge

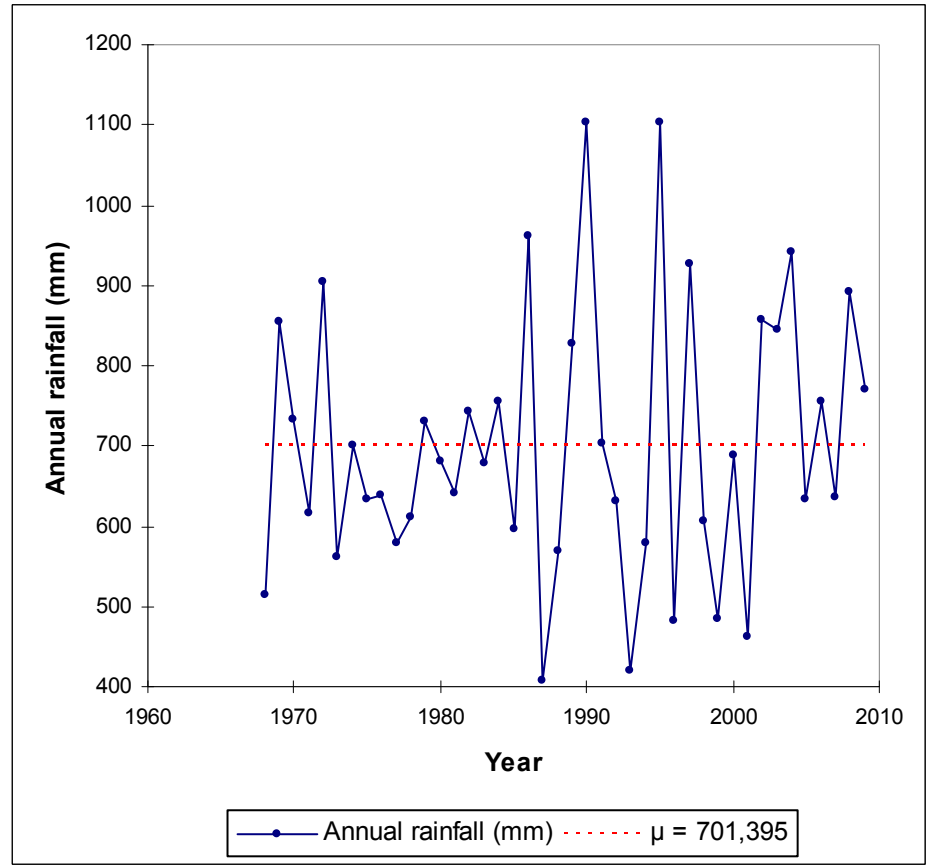

Figure 11. Test of Buishand for the annual precipitation, Ghézala-dam rain gauge 


\section{Discussion and conclusions}

This case study, using rainfall records of the Ichkeul basin, illustrates the independency between the durations of wet and dry events. It is shown that dry spells occur randomly during the rainy season. In this region dry spells can well be described by the negative binomial pdf. The procedure defines the inter-event time as being the dry event period. For the rainfall event duration, the theoretical requirement of the fitted geometric pdf are satisfied (Figure 7). It has to be pointed out that the event-based definition of the rainy season does not exactly fit the theoretical condition. Rainy seasons have variable lengths, as they are a stochastic function of the events themselves. For planning purposes, the longest dry spells associated with the various statistical recurrence periods are derived on the basis of the fitted GEV distributions. Event-based analysis is also useful to check the spatial properties of dry events. Event-based analysis, even if it is carried out on the basis of few years of observation, can rely on large number of data points (table 2). While the expected number of events/season is still derived from very few data, this estimate is more reliable than the approximate expected length of the longest seasonal dry spell, since this variability of the former is usually less than that of the latter, for the same data sets (table 10).

\begin{tabular}{|l|l|l|l|l|}
\hline Rain gauge & $\begin{array}{l}\text { No. of } \\
\text { data }\end{array}$ & $\begin{array}{l}\text { Coefficient of variation } \\
\text { of the number of dry } \\
\text { events-season (Cv1) }\end{array}$ & $\begin{array}{l}\text { Coefficient of } \\
\text { variation of } \\
\text { longest seasonal dry } \\
\text { event }\left(\mathbf{C v}_{\mathbf{2}} \mathbf{)}\right.\end{array}$ & $\mathbf{\mathrm { Cv } _ { 2 } / \mathbf { C v } \mathbf { 1 }}$ \\
\hline Ghézala-dam & 42 & 0.20 & 0.31 & 1.55 \\
\hline Oued J. Jebel Antra & 46 & 0.20 & 0.31 & 1.55 \\
\hline Sidi Salem & 51 & 0.20 & 0.35 & 1.75 \\
\hline Frétissa & 27 & 0.24 & 0.30 & 1.25 \\
\hline Sidi Abd el Basset & 28 & 0.25 & 0.36 & 1.44 \\
\hline
\end{tabular}

Table 10. Coefficient of variation of the number of dry events-season and that of the longest seasonal dry spell.

The procedure adopted allowed us to study the influence of climatic variation and the threshold value of negligible precipitation in identifying dry events. Another application of the event-based analysis is the study of the effects of climate change.

This study, which relied on daily data, describes characteristics of dry spell and their extreme cases. These features are important when estimating the drought risks. Although the region selected for study is not semi arid, data were not always available at the required level of detail. As a result, the detail of the studied events depended on the data collection stations involved. This lack of data is partially compensated by the daily series. In general, this study aimed to define droughts under specific conditions in terms of dry event. We also synthesised information for use in models of climatic risk, infrastructure damage mitigation and environmental management. 


\section{Adaptive measure in reponse to longest dry spells in the basin}

During 1987 - 1989 and 1993 - 1995 drought was characterized by two subsequent dry years. The drought management system has been applied. It was based on reactive decisions. The system is based in three phases: (i) Before drought (preparedness and early warning); (ii) Drought management (mitigation when drought is upon) and (iii) Subsequent drought (when drought is over). During each of the three phases different measures are applied. The Drought Management Phase is characterized by the execution of the planning programs of drought mitigation. Depending on the type, intensity and duration of the drought event, different scenarios are adopted [27].

The year is considered dry when the precipitation deficit is beyond $50 \%$ of the mean historically established value. The probability to have a dry year is 7 to $23 \%$ in the region. From such situation results a substantial shortage in the available water resources, a production falling and range shortage, and some problems related to the domestic water supply appear. Livestock sickness could be observed, because of diet change and unbalanced nutrition regime. In order to attenuate those problems a mitigation program is executed. For livestock safeguard, the identification of the animal nutriments stocks is established and an importation planning, if necessary, is fitted in order to gap the deficiency. Prevision of vaccination campaigning on the livestock against the sickness related to drought. To satisfy the domestic water demand, in urban as well as in rural areas, a program of aquifers uses is adopted, the use of the surface water resources is avoided or minimized. Particular attention is given to water transportation until the rural drought sensitive regions. Establishing reservoirs water management plan regarding the evolution of the climatic conditions. The eventuality of a second dry year is specially taken in account. Intensification of the preparedness operations related to the next year up going (short loans, soil tillage, seeds distribution ...). When drought is over, several measures are taken. This is the intensification of the vulgarization program related to the soil tillage and farming practices in order to maximize the valorisation of the precipitation coming during the subsequent drought wet year. Available water resources evaluation (reservoirs and aquifers) is made. Reconstitution of the aquifers water reserves by the artificial recharging is followed. Like other action initiated, evaluation of the mitigation program efficiency and estimation of their cost.

In the following, the hydrological drought in this basin, including the water resources reservoirs management under drought and the water supply conditions, is presented. It is important to underline those water resources reservoirs management involving the application of water supply rationing depends on water storage at end April. Rainfall deficit during the period between the beginning of September and end April is an important index indicating the water resources availability situation. This period is the most determining of the hydrological drought and its impact on the reservoirs storages.

During 1987 - 1989 drought was severe in the whole country. During this period the water catchments in the reservoirs has been less than 50\% of dams' capacity. During $1993-1995$ drought was similar to the former event described above. Rainfall deficit was ranged 
between 33 to $56 \%$ and was around $35 \%$ on the national scale. During this drought, data on the water catchments recorded in dams located in this region that were under exploitation in this date are presented in table 11.

\begin{tabular}{|c|c|c|c|}
\hline Dams & Use starting date & Minimal water input $\mathbf{( M m}^{\mathbf{3}} \mathbf{)}$ & Year \\
\hline Joumine & $1983-1984$ & 17.9 & $1993-1994$ \\
\hline Ghézala & $1984-1985$ & 0.5 & $1993-1994$ \\
\hline
\end{tabular}

Table 11. Minimal water input recorded in dams under exploitation located in this region

The decision tools used for water management, during 1992 - 1995, were based on the measurement instrumentation spread in the water supply locations, information and data transfer to the Central Direction for decision taking, the filed databases, specialized software and simulation models related to the water management optimization. The drinking water supply (for domestic ...) has been ensured without any restriction during the successive years 1992 - 1993, 1993 - 1994 and 1994 - 1995.

The agricultural water demand was satisfied during 1992 - 1993 and 1993 - 1994. A restriction plan was prepared for 1994 - 1995. This plan was applied in March 1995 and adapted in July 1995 regarding the water resources situation. For the irrigated areas, the restriction has been about $50 \%$ (with normal year as reference). This restriction ranged from 19.5 to $27.5 \%$ referring to a dry conditions year $(1993-1994)$. Therefore during this year (1993 - 1994), in spite of the dry conditions all agricultural demand was satisfied. Farmers adopted some "self modifications" in their farming systems to adapt them to drought situation [27].

From all the previous drought management events, actions related to agricultural production (crop systems and livestock care) were well monitored. It is from the practical decisions taken during 1992 - 1995 drought events that tools decisions linked to water reservoir management were tested.

\section{Author details}

Majid Mathlouthi

Research Laboratory in Science and Technology of Water in INAT, Tunis, Tunisia

Fethi Lebdi

National Agronomic Institute of Tunisia (INAT), University of Carthage, Tunis, Tunisia

\section{References}

[1] Wallis T. W. R, Griffiths J. F (1995) An assessment of the weather generator (WXGEN) used in the erosion/productivity impact calculator (EPIC). Agric. Meteorol. 73: 115-133.

[2] Semenov M. A, Brooks R. J, Barrow E. M, Richardson C. W (1998) Comparison of WGEN and LARS-WG stochastic weather generators for diverse climates. Clim. Res. 10: 95-107. 
[3] Cahill A. T (2003) Significance of AIC differences for precipitation intensity distributions. Advances in Water Resources 26(4): 457-464.

[4] Hui W, Xuebin Z, Elaine M. B (2005) Stochastic Modelling of Daily Precipitation for Canada. Atmosphere-Ocean 43 (1): 23-32.

[5] Muller A (2006) Comportement asymptotique de la distribution des pluies extrêmes en France. Thèse de l'Université de Montpellier II, Sciences et Techniques de Languedoc.

[6] Wilks D. S (1999) Interannual variability and extreme-value characteristics of several stochastic daily precipitation modes. Agric. Meteorol. 93: 153-169.

[7] Hayhoe H. N (2000) Improvements of stochastic weather data generators for diverse climates. Clim. Res. 14: 75-87.

[8] Mathlouthi M, Lebdi F (2008a) Event in the case of a single reservoir: the Ghèzala dam in Northern Tunisia. Stochastic Environ. Res. and Risk Assessment 22 : 513-528.

[9] Mathlouthi M, Lebdi F (2008b) Evaluation de la fiabilité de gestion d'un barrage réservoir pour des événements secs. Hydrol. Sci. J. 53(6): 1194-1207.

[10] Mathlouthi M, Lebdi F (2009a) Analyse statistique des séquences sèches dans un bassin du nord de la Tunisie. Hydrol. Sci. J. 54(3): 442-455.

[11] Mathlouthi M (2009) Optimisation des règles de gestion des barrages réservoirs pour des évènements extrêmes de sècheresse. Thèse de Doctorat, Institut National Agronomique de Tunisie, Tunis, Tunisie. 162 p. Available: http://www.birsa.agrinet.tn

[12] Mathlouthi M, Lebdi F (2010) Caractérisation des événements secs dans un bassin du Nord de la Tunisie. In: Eric Servat, Siegfried Demuth, Alain Dezetter \& Trevor Daniell, editors. Global Change: Facing Risks and Threats to Water Resources (Proc. of the Sixth World FRIEND Conference, Fez, Morocco, October 2010). IAHS Publ. 340, 2010. IAHS Press, Wallingford, UK. pp. 86-94.

[13] Rajagopalan B, Lall U (1999) A k-nearest-neighbor simulator for daily precipitation and other weather variables. Water Resour. Res. 35: 3089-3101.

[14] Mathlouthi M, Lebdi F (2009b) Emploi de la série chronologique des événements secs générés dans l'optimisation de la gestion des barrages. Hydrol. Sci. J. 54(5): 841-851.

[15] Longley R.W (1953) The length of dry and wet periods. Q J R Meteorol Soc 79: 520.

[16] Williams C.B (1952) Sequences of wet and of dry days considered in relation to the logarithmic series. Q J R Meteorol Soc 78(335): 91-96. doi:10.1002/qj.49707833514.

[17] Feyerherm A.M, Bark L.D (1967) Goodness of fit of a Markov chain model for sequences of wet and dry days. J Appl Meteorol 6: 770-773.

[18] Caskey J.E (1963) A Markov chain model for the probability of precipitation occurrence in intervals of various length. Mon Weather Rev 91: 298-301.

[19] Gringorten II (1971) Modelling conditional probability. J Appl Meteorol 10: 646-657.

[20] Naumann G, Vargas W, Minetti J.L (2008) Dry spells in the La Plata Basin. Monitoring and trend stability. Drought implication. Meteorologica 33: 61-85.

[21] Vargas W.M, Naumann G, Minetti J.L (2011) Dry spells in the River Plata Basin: an approximation of the diagnosis of droughts using daily data. Theor. Appl. Climatol. (2011) 104: 159-173. DOI 10.1007/s00704-010-0335-2. 
[22] Eagleson P. S (1978) Climate, soil and vegetation 2: The distribution of annual precipitation derived from observed storm sequences. Water Resources Research 14(5): 713-721.

[23] Bogardi J. J, Duckstein L, Rumambo O. H (1988) Practical generation of synthetic rainfall event time serie in semi-arid climatic zone. Journal of Hydrology 103: 357-373.

[24] Fogel M. M, Duckstein L (1982) Stochastic precipitation modelling for evaluating nonpoint source pollution. In: Singh V, editors. Statistical Analysis of Rainfall and Runoff (Proc. Int. Symp. on Rainfall-Runoff Modelling 1981). Water Resources Publications. Littleton, Colorado, USA. pp. 119-136.

[25] Mathlouthi M, Lebdi F (2008) Characterization of dry spell events in a basin in the North of Tunisia. Proceedings of the First International Conference on Drought management: Scientific and technological innovations. Zaragoza, Spain, June 12-14, 2008. In: Lopez-Francos A, editors. Drought management: Scientific and technological innovations (Options Méditerranéennes, Series A: Séminaires Méditerranéens 80). CIHEAM Pub.2008. pp. 43-48

[26] Lubès-Niel H, Masson J. M, Paturel J. E, Servat E (1998) Variabilité climatique et statistique. Etude par simulation de la puissance et de la robustesse de quelques tests utilisés pour vérifier l'homogénéité de chroniques. Revue des Sciences de l'Eau 11(3): 383-408.

[27] Louati M.H, Bergaoui M, Lebdi F, Mathlouthi M., El Euchi L, Mellouli H.J (2007) Application of the Drought Management Guidelines in Tunisia. In: Iglesias A, Moneo M, Lopez-Francos A, editors. Drought Management Guidelines Technical Annex. (Options Méditerranéennes Serie B n. 58). CIHEAM Pub.2007. pp. 417-467 